\title{
Correlates of Women's Labor Force Supply in Pakistan
}

\author{
Abdul Ghafoor Awan ${ }^{1 *}$, Zahir Faridi ${ }^{2}$, Shazia Bibi ${ }^{3}$ \\ ${ }^{1}$ Dean, Faculty of Management and Social Sciences, Institute of Southern Punjab, Multan, PAKISTAN \\ ${ }^{2}$ Director, School of Economics, Bahauddin Zakariya University, Multan, PAKISTAN \\ ${ }^{3}$ M.Phil. Economics Scholar, Department of Economics, Institute of Southern Punjab, Multan, PAKISTAN \\ *Corresponding Contact: \\ Email: drabdulghafoorawan@gmail.com
}

\begin{abstract}
This study has analyzed correlation among those variables that affect women working hours in labor market in Pakistan. We used primary data that was collected from the rural and urban areas of District Multan. A sample of 300 women having eight years education was taken randomly and formal questionnaire was constructed for this purpose. Ordinary Least Square method was applied for estimation of parameters. The results of our empirical study show that various variables have expected signs in analysis. We found that joint family setup, family expenditures, number of dependent, working days and wage rate impact positively and significantly to the working hours of women. In contrast, number of children, nuclear family size, etcare inversely related to the women working hours. Therefore, we suggest that there should be provision of better education for women to improve their working hours and participation rate in labor market.
\end{abstract}

Key Words: Labour Market, working hours, women participation, family size

\section{INTRODUCTION}

Labor Supply means total hours that an individual is willing to and able to work at a given wage rate. It is given by considering the decision to do work took by a person in the population. The estimates of labour force participation (LFP) determine the policy of employment and policies formed for the development of human resources. The women labor supply in labor market participates in socio-economic development of an economy and decrease the poverty. The population of women in Pakistan is nearly half of total population of the country. For this reason, it is necessary to estimate role of females in labour market of an economy along with economic development in the Pakistan.

In Pakistan rate of women labor force participation is relatively low due to lack of percentage participation in the economic working activities of the women, hence it is a major issue in development. The economists have paid special attention to women's role in working activities and economic development of Pakistan. In this study, we have tried to examine that how many demographic and other variables impact the working hours of the women in labor market. 


\section{LITERATURE REVIEW}

Fatima (2003) discussed the behavior of women's active participation in work force to reduce the levels of poverty. The OLS (Ordinary Least Square) method was employed to draw the results. It is concluded that when income is below the poverty line due to dominance of economic factors women decision to take part in working activities will rise and have negative elasticity of labour supply. It is also pointed out that wage rate and labour market experience have direct relation with women's labour supply. The study suggested that there should be specialized trainings and education programs to raise the interact of women labour market.

Faridiet. al. (2009a) explored the affect of education on women's labour powers supply in labour market. Data was collected through primary from different educational institutions of Bahawalpur District. This study not only estimated the earning function but also the returns to education at various stages. It is concluded that coefficients of all level of education have significant impacts in female labour supply in labour market.

Abbas (2013) measured the effect of various factors on women's labour supply in Pakistan and Bangladesh during the period of 1980-2011. The time series data from (1980-2011) used in the study that was obtained from World Bank database. He used Vector Error Correction Model (VECM) which is a restricted model of the standard (VAR) model. The results of the study explained that mostly variables showed expected signs for these two economies. Finally the conclusion of the study represented positive shock is more in both countries.

Akinware (1988) reported pattern of childcare cost and women's participation in working activities within the Yoruba rural settlement of Oyo and Owo local government area in Nigeria. The majority of mothers face a heavy workload with a high childcare load of two children under six years old on average. It is concluded that mother's earning activities indicates needs for childcare cost and childcare centers.

Awan et al (2015) says that most the labour worked in agriculture sector is women who significantly contribute in sowing and harvesting of crops. If women labour force is not available in rural areas, the agriculture sector of Pakistan badly suffers and cost of production is increased significantly, bringing negative impact on farmers' income.

Awan et al (2015) also disclosed that women play an important role in household budget in urban areas of Pakistan. Particularly, educated women's contribution in household budget is rapidly increasing because of their handsome earning from jobs. In contrast, rural women's contribution in household budget is not significant because they work in agriculture field just to support their spouse. Moreover, the women working on daily wages in the rural areas earn nominal income, which is mostly consumed.

Awan and Zertasia (2015) contend that women empowerment is the real factor that motivates women to exercise their capabilities and increase their skills. The growing education and women participation in executive jobs is also increasing women's contribution in family development and better nourishment of their children.

Riber (1995) examined women's labour supply and childcare expenditure. The results indicate that cost of childcare expenditure has negative impact on women's labour force supply. They suggested that subsidy program as child and dependent care tax credit have significant impacts on women's labour supply in labour market. 
Chuykowski and powell (1999) observed recent women's progress in the last three decades especially in relation to males. The secondary data was used in this study which was collected from different sources as labour force survey etc. Finally, it is concluded that policy issues related to the trends and female's position in labour market. It is suggested that improvement in female's level of education provision of technical and skillful education plays a vital role in women's labour force participation.

Joumotte (2003) examined the determinants which effects female labour supply in labour market in OCED countries. He concluded that female education, general labour market condition, culture and attitude are major factors of female labour force participation. It is suggested that increase in female labour supply not based on cost of reduction of fertility while based on appropriate work family reconciliation policies.

Alcaino (2009) explored the changes in labour force participation (working and unemployed) over total female's population. The control variable was changes in the labour measurement methodology. The study concluded that wages have positive impact on women's participation. While leisure time, consumption, fertility and life expectancy are negatively related to the women's participation.

Owuamanam and Alwolodu (2010) analyzed the relationship between parent's education and income with their family size. The finding of the study was that education and income are significantly correlated to family size. It is suggested that there should be guidance counselors and social health workers which help parents in planning for their family size.

\section{Research Methodology}

Data and Type: We collected primary data through a questionnaire from central part of Multan city. The questions in the questionnaire were related to the education, age, household income, family size, family type, marital status, and education of close relatives, expenditures location and other demographic variables. Information about the working hours was also collected to determine how many hours' women are allocating to work and homes.

Sample of Study: To explore the trends of women labor force participation and effects of different correlates on women labor force participation decision in labor market. 300 educated women were selected as a sample of study and their face-to-face interviews were conducted. It was noted during the study that the job opportunities are high in main city areas as compared to the tehsils, towns and villages and distance areas.

Model specification: We developed the following model for our study:-

$\mathrm{Yi}=\mathrm{b} 0+\mathrm{b}_{1} \mathrm{X}_{1 \mathrm{i}}+\ldots \ldots+\mathrm{b}_{\mathrm{k}} \mathrm{X}_{\mathrm{ki}}+\mathrm{u}_{\mathrm{i}}$

Yi indicates the dependent variable women working hours in labor market

$\mathrm{Xi}$.......Xk indicates the independent variables in the model

$\mathrm{u}_{\mathrm{i} . . . .}$ represents the error term of the model

To examine the impacts of different casual variables on women's labor force participation in labor market we estimate the following model.

WWHR $=\alpha+\beta 1 Y A G E+\beta_{2}$ YEDU $+\beta_{3}$ MART $+\beta_{4} \mathrm{LCTN}+\beta_{5} \mathrm{H} / \mathrm{FMIN}+\beta_{6} \mathrm{H} / \mathrm{FEMP}+$ $\beta_{7} \mathrm{WWDW}+\beta_{8} \mathrm{FyIN}+\beta_{9} \mathrm{FyEX}+\beta_{10} \mathrm{NODT}+\beta_{11} \mathrm{NOCH}++\beta_{12} \mathrm{FYRS}+\beta_{13} \mathrm{HYRS}+\mathrm{u}_{\mathrm{i}}$ 


\section{DATA ANALYSIS}

Education of a respondent is an important factor, which influenced the decision of participation of women in labour market. This has been estimated that the higher the level of education among females raises the participation rate in labour market. Because education increases the productivity of a worker and make them skillful as compared to low level of education. Table 1 shows that out of a sample of 300 participants, women highest participation rate is at master and bachelor level of education is $41.67 \%$ and $32.67 \%$ participation with bachelor level of education

Table 1Years of Schooling and women participation

\begin{tabular}{|l|cc|}
\hline Years of Schooling of Women & \multicolumn{2}{|c|}{ Participating Women } \\
\hline Upto Matriculation & 31 & $(10.33 \%)$ \\
\hline Intermediate & 46 & $(15.33 \%)$ \\
\hline Bachelor & 98 & $(32.67 \%)$ \\
\hline Master & 125 & $(41.67 \%)$ \\
\hline Total & 300 & $(100 \%)$ \\
\hline
\end{tabular}

Source: Field Survey Conducted by Author

While labour force participation rate of females with matriculation and intermediate level is $10.33 \%$ and $15.33 \%$ respectively. Low participation rate may be due to low skills and lower level of education. With intermediate and matriculation females have lower opportunity of good jobs so participation rate is low at this level of education. There is number of job opportunities for females who have completed high level of education they can achieve many benefits from their jobs as they earn high hourly wages and have opportunity of maternity leave as well. While the females with lower education level cannot enjoy these benefits and face the problem of bad condition of work, low pay etc.

Table 2: Participation rate of Women on the basis of Location

\begin{tabular}{|l|l|}
\hline Location & Working Women \\
\hline Rural & $98(32.66 \%)$ \\
\hline Urban & $202(67.33 \%)$ \\
\hline Total & 300 \\
\hline
\end{tabular}

Source: Field Survey Conducted by Author

Table 2 shows that $67.33 \%$ women belonged to the urban area of the district Multan. The participation rate of urban women is higher than the rural women participation rate, which is $32.66 \%$. It is due to the provision of better facilities than rural women such as better education, health and many other facilities. The participating women mostly involved in teaching, embroidery work, farming, health worker and many other types of economic activities, which is relatively low as compared to the urban women participation rate.

Table 3: Women participation rateon the basis of Marital Status

\begin{tabular}{|l|l|}
\hline Marital Status & Working \\
\hline Married & $149(49.67 \%)$ \\
\hline Unmarried & $110(36.67 \%)$ \\
\hline Others (Separated, Divorced and Widows) & $41(13.66 \%)$ \\
\hline Total & 300 \\
\hline
\end{tabular}

Table 3 shows participation rate of women by marital status. We observed that married women take part more in work force than the single women. $49.67 \%$ of participating women are married $36.67 \%$ are unmarried while $13.66 \%$ are others (widow, separated and 
divorced).The data shows that married women participate more in econometric activities than the unmarried women for the provision of basic needs of life of their family.

Table 4: Women participation rate by their Family Setup

\begin{tabular}{|l|l|}
\hline Family Setup & Working Females \\
\hline Joint family & $167(55.67 \%)$ \\
\hline Nuclear family & $133(44.33 \%)$ \\
\hline Total & 300 \\
\hline
\end{tabular}

Source: Field Survey Conducted by Author

Table 4 reflects that family setup is also a vital factor that contributes in the women participation in labor market. It was noted that women who live in a joint family setup participate relatively more than women who live in a separate family. As data shows that $55.67 \%$ women participant belongs to joint family setup while $44.33 \%$ belong to separate families. We observed that in joint family setup number of old age people and children are present and old age people remain at home and look after the children while a woman can participate in labor market easily whereas in separate family setup there is no one to take care of the children at home. So women who belong to individual family setup cannot easily participate in economic activities.

Table 5: Women Participation rate by Income (Monthly Wages in Pak Rs.)

\begin{tabular}{|l|l|}
\hline Monthly Income of The Women & Working Women \\
\hline Upto 3999 & $31(10.33 \%)$ \\
\hline $4000-7999$ & $50(16.66 \%)$ \\
\hline $8000-11999$ & $56(18.66 \%)$ \\
\hline $12000-15999$ & $65(21.66 \%)$ \\
\hline $16000-19999$ & $26(8.66 \%)$ \\
\hline $20000-23999$ & $16(5.33 \%)$ \\
\hline $24000-27999$ & $9(3 \%)$ \\
\hline $28000-29999$ & $8(2.66 \%)$ \\
\hline Above 30000 & $43(14.33 \%)$ \\
\hline Total & $300(100 \%)$ \\
\hline
\end{tabular}

Source: Field Survey Conducted by Author

Monthly income of the working female is also an important factor. In Table 5 shows mixed trend among labor force participation of women in labor market and monthly wage income. We have observed that up to the Rs.16000 monthly wages of the women participation rise while participation rate decreases below wage income of Rs. 30000. While women participation rate increase above Rs. 30000 wage income. It may be due to the different level of education and job opportunities available in Multan city.

Table 6: Women Participation rate by different age groups

\begin{tabular}{|l|l|}
\hline \multicolumn{1}{|c|}{ Different Age Groups } & Working Women \\
\hline $16-25$ years & $58(19.33 \%)$ \\
\hline $26-35$ years & $147(49.01 \%)$ \\
\hline $36-45$ years & $76(25.33 \%)$ \\
\hline $46-55$ years & $16(5.33 \%)$ \\
\hline $56-65$ years & $3(1 \%)$ \\
\hline Total & $300(100 \%)$ \\
\hline
\end{tabular}

Source: Field Survey Conducted by Author 
Table 6 shows that the involvement in economic activities of women in the age group of 16-25 years is low, e.g. $19.33 \%$.The females of this age group mostly have incomplete their level of education so they involved to complete their studies, because due to low level of education there is very less opportunities of good job. The females in the age group of $26-35$ years participate relatively more in working activities than other age groups (49.01\%).The apparent reason is that females in this group have completed their education, having required skills and training and are highly energetic in this group of age and can perform their job very well. While the females in age group of $55-64$ have less participation in economic activities because in this age they are less energetic and productive because of poor health.

Table 7: Women Participation rate by Experience (Years)

\begin{tabular}{|l|l|}
\hline Year of Experience & Working Women \\
\hline Upto 5 years & $110(36.66 \%)$ \\
\hline $5-10$ & $133(44.33 \%)$ \\
\hline $10-15$ & $34(11.33 \%)$ \\
\hline $15-20$ & $13(4.34 \%)$ \\
\hline Above 20 years & $10(3.34 \%)$ \\
\hline Total & 300 \\
\hline
\end{tabular}

Source: Field Survey Conducted by Author

Table 7 depicts the relationship between experience and women labour force participation rate. We observed that as the age of women increases their working ability decreases. Up to some years, experience of working women raises their productivity, but after that their productivity starts to decline due to old age. From our sample of 300 working women, highest rate of experience of women is up to 10 years which is $44.33 \%$.After above 20 years experience the participation rate of women decreases drastically to 3.34 percent.

Table 8: Women Participation rate w.r.t Head of Household Employed

\begin{tabular}{|l|l|}
\hline Head of Household & Working women \\
\hline Employed & $127(42.33 \%)$ \\
\hline not employed & $173(57.67 \%)$ \\
\hline Total & $300(100 \%)$ \\
\hline
\end{tabular}

Source: Field Survey Conducted by Author

It is observe that female whose head of household: her father or husband, is employed, their participation rate is low as compared to a women whose head of household is not employed. Out of 300 working women 173(57.67\%) are those, whose husband or father is not employed. There is insignificant relation among women participation and head of household employed. There is also negative relationship among female participation and other persons are also employed of the family. Only $30.67 \%$ participation is from those families from which other persons are employed, while $69.33 \%$ women are from those families from which no one is employed.

Table 9: Women participation rate by other person Employed

\begin{tabular}{|l|l|}
\hline Other person Employed or Not & Working Women \\
\hline Employed & $92(30.67 \%)$ \\
\hline not Employed & $208(69.33 \%)$ \\
\hline Total & $300(100 \%)$ \\
\hline
\end{tabular}

Source: Field Survey Conducted by Author 
Number of dependent is also an influencing factor affecting participation rate of women in labour market. Table 9 shows that number of dependent is directly relate to the decision of women participation in working activities. As number of dependent rises, women participation also rises such as when there is number of dependent in the family is 0 the rate of participation is $13.67 \%$. When number of dependents is more than 6 then participation rate is $27.67 \%$ which is highest rate. As number of dependents increase in the family the financial burden also increases which force the women to participate in labour market to share financial and economic burden. This shows positive relation between women decision to participate and number of dependents. The descriptive analysis of the collected data represents that women working hours decline with increase in women's family income. The income of the family is one of the major and important correlate to determine the women working hours.

\section{ECONOMETRIC ANALYSIS}

We examined the working hours of women to explore the influence of different factors contributing in the decision of women to participate in economic activities. We developed an econometric model and used Ordinary Least Square (OLS) method to estimate the parameters of the model. The results obtained from econometric analysis are given in Table 1 . The levels of significance are $1 \%, 5 \%$ and $10 \%$. The values of $R$ square $\left(R^{2}\right)$ is 0.45 , which indicates that independent variables bring $45 \%$ changes in dependent variable (WWHR). All variables are significant other than other person employed in the family, head of family employed, income of head of the family and location. The results show that year of age of the working women is positively related to the working hours. The data in Table 10 shows $0.021 \%$ variations to the women working hours with one unit change in age of the worker. Education of participating women is very important determinant to measure working hours in labour market. Years of education is positively related to the woman working hours and indicates $0.26 \%$ variations in dependent variable with one unit change in level of education. Our analysis shows that the relationship between locations is negative to the women working hours. The working hours of the women decrease by 0.003 due to increase in urban residence of women from rural area.

Table 10: Econometric Results

\begin{tabular}{|l|l|l|l|l|}
\hline Variable & Coefficient & Std. Error & t-Statistic & Prob. \\
\hline C & 3.543588 & 1.269982 & 2.790266 & 0.0056 \\
\hline AGEY & 0.021868 & 0.011067 & 1.976014 & 0.0491 \\
\hline YEDU & 0.267366 & 0.036043 & 7.417934 & 0.0000 \\
\hline FSTP & 0.117474 & 0.137289 & 0.855669 & 0.3929 \\
\hline FYEX & $2.04 \mathrm{E}-05$ & $2.05 \mathrm{E}-05$ & 0.995519 & 0.3204 \\
\hline FYIN & $-1.93 \mathrm{E}-05$ & $1.90 \mathrm{E}-05$ & -1.014525 & 0.3112 \\
\hline F/HMIN & $-8.70 \mathrm{E}-07$ & $6.37 \mathrm{E}-06$ & -0.136622 & 0.8914 \\
\hline LCTN & -0.003997 & 0.123471 & -0.032375 & 0.9742 \\
\hline LNFYSZ & 0.338767 & 0.314822 & 1.076060 & 0.2828 \\
\hline MART & 0.219531 & 0.180751 & 1.214549 & 0.2256 \\
\hline MINF & $1.29 \mathrm{E}-05$ & $9.51 \mathrm{E}-06$ & 1.360224 & 0.1749 \\
\hline NOCH & -0.204738 & 0.075230 & -2.721508 & 0.0069 \\
\hline NODT & 0.011685 & 0.051407 & 0.227314 & 0.8203 \\
\hline R-squared & 0.451926 & Mean dependent var & 7.903333 \\
\hline Adjusted R-squared & 0.397602 & F-statistic & 9.970449 \\
\hline Log likelihood & -390.8598 & Prob(F-statistic) & 0.000000 \\
\hline
\end{tabular}


The women who belong to joint family setup have more time to take part in labour market. The relation between family setup and women working hours is positive and significant to the women working hours. If one more women relate to joint family setup the women's working hours probability raised by 0.12 .The reason is that the women that belongs to joint family setup have less responsibilities toward household work and child caring, etc due to sharing and substitution of these activities. While women that belong to nuclear family setup have less time to spend in labor market because of burden of household activities and child caring. Monthly income of husband of a woman has negative and insignificant impact on women working hours. When income of the husband of women increases, it reduced the women working hours in labor market. If expenditure of the family is higher than the income of family then female productivity of working hours in labor market will increase.

The family income is a correlate that plays an immense character in women working hours. If income of a family is high then women working hours will be reduced. If the income of a family is raised then women working hours will reduced. Our results are consisted with the results of Hamid (1991) and Kazi \& Raza, (1991). The variable head of household employed is an important correlate of women working hours and have inverse relation with women working hours. If head of household is employed it reduces women working hours in labour market. When there are some other family members are also employed then it has negative impact on women working hours. Our results consistent with the results of Naqvi and Shehnaz (2002). Number of dependent is positively related to the women working hours. Number of dependent is significant at $10 \%$. When number of dependent increased in a family it increases the women working hour in labour market. It increases the responsibilities of women to share family burden by devoting some hours to work in the market.

\section{CONCLUSION}

In this empirical study, we examined the effect of different regressors to the women working hours in labor market and log linear earning function of women of Multan District. The evidence shows that various variables have expected signs in empirical analysis. The correlates that have been affecting positively and significantly to the women working hours are family expenditures, woman level of education, joint family setup, husbands years of schooling, Number of dependent, days of work. While income of head of household, number of children of preschool, family setup etc have inverse relation to the women working hours in labor market.

\section{RECOMMENDATIONS}

On the basis of our empirical analysis, we have made the recommendations:-

- Maximum educational institutions should be established in rural areas to provide technical education to the women.

- The Govt. should arrange the training and skill development programs to enhance the working skills of women.

- To encourage the women to spend more time in working activities.

- Public and private sectors should provide resources and necessary facilities for childcare such as educational facilities and childcare facilities for school-going children of working women. 


\section{REFERENCES}

Alcaíno, M. L. C. (2009). Women's Labor Force Participation in Chile, 1854-2000. Pontificia Universidad Católica de Chile, Instituto de Sociología.

Awan, A. (2014). Brazil's Innovative Anti-Poverty \& Inequality Model. American Journal Of Trade And Policy, 1(2), 56 - 61.

Awan, A. (2015). Shifting Global Economic Paradigm. Asian Business Review, 4(3), 35-40. doi: http://dx.doi.org/10.18034/abr.v4i3.264

Awan, A., \& Imran, M. (2015). Factors Affecting Food Price Inflation in Pakistan. ABC Journal Of Advanced Research, 4(1), 74 - 88.

Awan, A., \& Juiya, M. (2015). Role of Microfinance in Poverty Alleviation: Evidence from Pakistan. American Journal Of Trade And Policy, 2(1), 37 - 44.

Awan, A., \& Khan, R. (2014). The Enigma of US Productivity Slowdown: A TheoreticalAnalysis. American Journal Of Trade And Policy, 1(1), 7 - 15.

Awan, Abdul Ghafoor and Zertashia (2015) "Determinants of Women Empowerment: A Case study of District D.G.Khan" Journal of Developing Country Studies, Vol 5 (14) : 65-73.

Awan, Abdul Ghafoor Awan, Nasir Nadeem, Beenish Zaheen (2015) Factor Effecting the Rural Women Labour Supply in Agriculture Sector: A case study of District Rajanpur-Pakistan" Journal of Developing Country Studies, Vol 5 (1): 1-6.

Awan, Abdul Ghafoor, Zahir Faridi, Mujahid Abbas (2015) "Factors Affecting Women Contribution in Household Budget in Urban Informal Sector: An Analysis" Global Journal of Human Social Science \& Economics.Vol.15 (2 Version 1.0):5-15.

Chaykowski, R. P., \& Powell, L. M. (1999). Women and the labour market: Recent trends and policy issues. Canadian Public Policy/Analyse de Politiques, S1-S25.

Faridi, M. Z., Chaudhry, I. S., \& Anwar, M. (2009). The socio-economic and demographic determinants of women work participation in Pakistan: evidence from Bahawalpur District. A Research Journal of South Asian Studies, 24(2), 351-367.

Hamid, S., \& Al-Jalali, S. Z. (1991). Determinants of the Supply of Women in the Labour Market: A Micro Analysis [with Comments]. The Pakistan Development Review, 30(4), 755-766.

Jaumotte, F. (2003). Female labour force participation: past trends and main determinants in OECD countries.

Kazi, S., \& Raza, B. (1991). Duality of female employment in Pakistan. Pakistan Development Review

Kimmel, J. (1992). Childcare and the employment behavior of single and married mothers.

Naqvi, Z. F., Shahnaz, L., \& Arif, G. M. (2002). How do women decide to work in Pakistan?[with comments]. The Pakistan Development Review, 495-513.

Owuamanam, T. O., \& Alowolodu, O. (2010). Educational pursuit and income as correlates of family size in Ondo State, Nigeria. Journal of Social Sciences, 23(2), 123-127. 
Publish Online and Print Version Both ISSN Online: 2307-9592 